\title{
Miconazole induces apoptosis via the death receptor 5-dependent and mitochondrial-mediated pathways in human bladder cancer cells
}

\author{
SHEAU-YUN YUAN ${ }^{1,5}$, MING-YUH SHIAU ${ }^{5}$, YEN-CHUAN OU ${ }^{1,2}$, YU-CHIA HUANG ${ }^{3}, \mathrm{CHENG-CHE} \mathrm{CHEN}^{1}$, \\ CHEN-LI CHENG ${ }^{1}$, KUN-YUAN CHIU ${ }^{1}$, SHIAN-SHIANG WANG ${ }^{1,4,6}$ and KAN-JEN TSAI ${ }^{3}$ \\ ${ }^{1}$ Division of Urology, Department of Surgery, and ${ }^{2}$ Department of Education and Research, \\ Taichung Veterans General Hospital, Taichung 40705; ${ }^{3}$ Department of Medical Laboratory and Biotechnology, and \\ ${ }^{4}$ School of Medicine, Chung Shan Medical University, Taichung 40201; 5 Department of Nursing, Hung Kung University, \\ Taichung 43302; ${ }^{6}$ Department of Applied Chemistry, National Chi Nan University, Puli, Nantou 54561, Taiwan, R.O.C.
}

Received September 24, 2016; Accepted January 26, 2017

DOI: $10.3892 /$ or.2017.5608

\begin{abstract}
Miconazole (MIC), an antifungal agent, diplays anti-tumorigenic activity in various types of human cancers, including bladder cancer, yet its mechanism of antitumor action is not well understood. In the present study, we demonstrated that, in a cell viability assay, MIC had a cytotoxic effect on human T24, J82 and TSGH-8301 bladder cancer cells in a dose- and time-dependent manner, but did not exhibit significant toxicity toward human peripheral blood mononuclear cells. Cell cycle analysis revealed that MIC at concentrations of 25 and $50 \mu \mathrm{M}$ significantly caused $\mathrm{G} 0 / \mathrm{G} 1$ arrest in the TSGH-8301 and T24 cells, respectively. DNA fragmentation, mitochondrial membrane potential and western blot analyses showed that MIC inhibited the growth of these cells by both mitochondrial-mediated and death receptor (DR5)-mediated apoptosis pathways. Specifically, MIC increased the protein levels of p21 and p27, but decreased the expression of cyclin E1, CDK2 and CDK4. MIC augmented the expression of DR5,
\end{abstract}

Correspondence to: Professor Kan-Jen Tsai, Department of Medical Laboratory and Biotechnology, Chung Shan Medical University, No. 110 Section 1, Jianguo N. Road, Taichung 40201, Taiwan, R.O.C.

E-mail:kjt@csmu.edu.tw; kanjentsai@gmail.com

Dr Shian-Shiang Wang, Division of Urology, Department of Surgery, Taichung Veterans General Hospital, No. 1650 Section 4, Taiwan Boulevard, Situn, Taichung 40705, Taiwan, R.O.C.

E-mail:sswdoc@vghtc.gov.tw

Abbreviations: MIC, miconazole; PARP, poly(ADP-ribose) polymerase; NAC, $N$-acetyl-L-cysteine; MTT, 3-(4,5-dimethylthiazol -2-yl)-2,5-diphenyltetrazolium bromide; MTS, 3-(4,5-dimethylthiazol-2-yl)-5-(3-carboxymethoxyphenyl)-2-(4-sulfophenyl)-2Htetrazolium, inner salt

Key words: miconazole, G0/G1 arrest, death receptor 5, p53, cytochrome $c$, apoptosis, bladder cancer cell lines cleaved forms of caspase-3 -8 and -9, poly(ADP-ribose) polymerase and Bax, decreased the expression of Bcl-2 but increased cytosol levels of cytochrome $c$. Our results suggest that MIC inhibits the growth of bladder cancer cells through induction of G0/G1 arrest and apoptosis via activation of both the extrinsic and intrinsic apoptotic pathways. MIC is a potential chemotherapeutic agent for treating bladder cancer in humans.

\section{Introduction}

Triazoles, including miconazole (MIC), ketoconazole (KT) and fluconazole (FT), are used as fungicides in agriculture and as antifungal drugs in humans $(1,2)$. Topical MIC is efficacious for the treatment of most mycoses (3-5). MIC buccal tablets have recently been approved by the US Food and Drug Administration for the treatment of oropharyngeal candidiasis in human immunodeficiency virus (HIV)-infected patients (6). MIC alters the fungal cell membrane, and exerts its therapeutic effect mainly by inhibiting fungal ergosterol biosynthesis (7). Additionally, MIC inhibits a variety of cytochrome P-450-dependent enzymes (8).

Recent evidence suggests that triazoles exhibit antiproliferative effects, and are modified on their 1,2,4-triazole nucleus to generate different types of anticancer agents (9). MIC has also been shown to be an effective anticancer drug. For example, MIC was found to inhibit the proliferation of human acute myelogenous leukemia (10) and breast and bladder cancer cells (11), and to induce apoptosis through G0/G1 cell cycle arrest in some types of human colorectal cancer cell lines (12). Other studies have revealed that MIC may inhibit melanogenesis in B16 cells and that MIC may be useful in the treatment of hyperpigmentation disorders, such as ephelis and melasma (13). Furthermore, 10-100 $\mu \mathrm{M}$ MIC was found to decrease cell proliferation rates in human osteosarcoma cells in a concentration-dependent manner and to increase intracellular $\mathrm{Ca}^{2+}$ levels in these cells, mainly from the endoplasmic reticulum, independent of phospholipase $\mathrm{C}$ activity and external $\mathrm{Ca}^{2+}$ influx (14). 
Although these findings demonstrate the antitumor activity of MIC, the mechanism underlying the effect of MIC on bladder cancer remains unknown. In the present study, we evaluated the effect of MIC on bladder cancer cell apoptosis and characterized its underlying molecular mechanism.

\section{Materials and methods}

Cell culture and reagents. Human bladder cancer cell lines T24 (p53-mutant) and TSGH-8301 (wild-type p53) were purchased from the Bioresource Collection and Research Center (BCRC; Hsinchu, Taiwan). The J82 (p53-mutant) cell line was purchased from the American Type Culture Collection (ATCC; Rockville, MD, USA). Peripheral blood mononuclear cells (PBMCs) were obtained from healthy donors. All of these cells were cultured in RPMI medium supplemented with $10 \%$ fetal bovine serum (FBS) (Gibco, Gaithersburg, MD, USA) and 1\% antibiotic-antimycotic solution. Cells were incubated at $37^{\circ} \mathrm{C}$ with $5 \% \mathrm{CO}_{2}$. Miconazole nitrate was purchased from Sigma-Aldrich (St. Louis, MO, USA). MIC was prepared in dimethyl sulfoxide (DMSO) to a final concentration of $0.2 \mathrm{mmol} / \mathrm{l}$.

Cytotoxicity assay. The cytotoxicity of MIC in T24, and TSGH-8301 cells and PBMCs was determined using the 3-(4,5-dimethylthiazol-2-yl)-2,5-diphenyltetrazolium bromide (MTT) assay (Sigma-Aldrich), which was performed as previously described (14). The 3-(4,5-dimethylthiazol-2-yl)-5(3-carboxymethoxyphenyl)-2-(4-sulfophenyl)-2H-tetrazolium (MTS) assay (Promega, Madison, WI, USA) was performed according to the manufacturer's instructions. Cells were seeded on 96-well plates for $24 \mathrm{~h}$, and then treated with pifithrin- $\alpha$ (PFT- $\alpha$ ), NAC or caspase inhibitors with and without MIC at $50 \mu \mathrm{M}$. After incubation for $24 \mathrm{~h}, 20 \mu \mathrm{l}$ of CellTiter 96 Aqueous One Solution Reagent (Promega) was added to each well and incubated for 1-4 h followed by absorbance reading at $490 \mathrm{~nm}$.

Flow cytometry. Cells $\left(1 \times 10^{6}\right)$ were treated with MIC for $24 \mathrm{~h}$. All cells were collected after trypsinization followed by fixation and permeabilization with $70 \%$ ethanol at $-20^{\circ} \mathrm{C}$ overnight. After washing with ice-cold phosphate-buffered saline (PBS), the cells were incubated with propidium iodide solution (PI: $0.2 \mathrm{mg} / \mathrm{ml}$, RNase: $20 \mu \mathrm{g} / \mathrm{ml}, 0.1 \%$ Triton X-100) for $30 \mathrm{~min}$ at room temperature, in the dark. Flow cytometry was performed using WinMDI v2.9 (Scripps Research Institute, La Jolla, CA, USA). Ten thousand events/sample were counted for triplicate experiments.

DNA fragmentation analysis. Cells were treated with various concentrations of MIC. At indicated time points, the cells were collected by $0.25 \%(\mathrm{v} / \mathrm{v})$ trypsin digestion, followed by centrifugation at 2,000 x g for $10 \mathrm{~min}$. Cells were lysed in $800 \mu \mathrm{l}$ of lysis buffer (50 mM Tris, pH 8.0, $10 \mathrm{mM}$ EDTA and $0.3 \%$ Triton X-100), and treated with RNase $(0.1 \mathrm{mg} / \mathrm{ml})$ followed by proteinase $\mathrm{K}$. The extracted DNA was electrophoresed on $2 \%$ agarose gels and stained with ethidium bromide (15).

Western blotting. Equal amounts of protein (measured by Bradford assay) were loaded on 10-15\% sodium dodecyl sulfate polyacrylamide gels, transferred to polyvinylidene fluoride
(PVDF) membranes, and blocked with 5\% non-fat milk in Tris-buffered saline and Tween-20 (TBST) buffer (20 mM Tris-HCl, $120 \mathrm{mM} \mathrm{NaCl}, 0.1 \%$ Tween-20). The membranes were incubated with antibodies against TNF-related apoptosis-inducing ligand (TRAIL), death receptors (DR4 and DR5) (1:1,000; Santa Cruz Biotechnology, Inc., Santa Cruz, CA, USA), DR5 (1:10,000; Abcam, Cambridge, MA, USA), $\beta$-actin, Bcl-2, Bax, caspase-3, -8 and -9 , poly(ADP-ribose) polymerase (PARP) (1:1,000; Cell Signaling Technology, Boston, MA, USA), cytochrome $c(1 \mu \mathrm{g} / \mathrm{ml}$; from BD Pharmingen, San Diego, CA, USA), Smac/DIABLO, cyclin D1, cyclin-dependent kinase 2 (CDK2), CDK4 (1:1,000; GeneTex, Hsinchu City, Taiwan), p53, p21, p27 and cyclin E1 (1:1,000; Epitomics, Burlingame, CA, USA) at $4^{\circ} \mathrm{C}$ overnight. After washing, the blots were incubated with horseradish peroxidase-labeled secondary antibodies for $1 \mathrm{~h}$, and visualized using enhanced chemiluminescence.

Mitochondrial membrane potential assay. Cells were seeded onto $10-\mathrm{cm}$ dishes and treated with various concentrations of MIC for $24 \mathrm{~h}$, followed by staining with $5 \mu \mathrm{M} \mathrm{JC}-1$ (Invitrogen, Carlsbad, CA, USA) for $30 \mathrm{~min}$ at $37^{\circ} \mathrm{C}$. Fluorescence was monitored using a plate reader at wavelengths of $490 \mathrm{~nm}$ (excitation)/540 nm (emission) and $540 \mathrm{~nm}$ (excitation)/590 nm (emission). Mitochondrial membrane potential $(\Delta \psi \mathrm{m})$ changes were indicated by the changes in the ratio of $590 \mathrm{~nm}$ (red) to $540 \mathrm{~nm}$ (green) fluorescence.

Reactive oxygen species detection. Intracellular reactive oxygen species (ROS) were determined using the fluorescent superoxide indicator dihydroethidium (DHE; Setareh Biotech, LLC, Eugene, OR, USA) (16-19). T24 and TSGH-8301 cells were treated with $50 \mu \mathrm{M}$ MIC for 8,16 or $24 \mathrm{~h}$, and then incubated with $2 \mu \mathrm{M} \mathrm{DHE}$ in serum-free medium, at $37^{\circ} \mathrm{C}$ for $15 \mathrm{~min}$, and then analyzed by flow cytometry.

Statistical analyses. Statistical comparisons were performed using unpaired, two-tailed Student's t-tests. p-values of $<0.05$ were considered to indicate a statistically significant result.

\section{Results}

MIC is cytotoxic to T24, J82 and TSGH-8301 cells. We determined the cytotoxic effect of various concentrations of MIC (Fig. 1A) on T24, J82 and TSGH-8301 cells using the MTT assay. The cell viability of both T24 (p53 mutant) and TSGH-8301 ( $p 53$ wild-type) cells was lower than that of the J82 bladder cancer cells after treatment with $50 \mu \mathrm{M}$ MIC. We therefore chose T24 and TSGH-8301 cells for further assays. MIC exhibited cytotoxic effects in a concentration- and time-dependent manner (Fig. 1B and C). After MIC treatment for 24,48 and $72 \mathrm{~h}$, the $\mathrm{IC}_{50}$ values were estimated to be $47.5 \pm 0.5,42.0 \pm 1.8$ and $37.3 \pm 0.3 \mu \mathrm{M}$, respectively, in the T24 cells; and $45.9 \pm 0.4,32.2 \pm 0.8$ and $29.4 \pm 0.2 \mu \mathrm{M}$, respectively, in the TSGH-8301 cells. Treatment of PBMCs with $100 \mu \mathrm{M}$ MIC for $24 \mathrm{~h}$ showed a lower cytotoxic effect (85\% cell-survival rate) than that noted in the bladder cancer cells (Fig. 1B). Thus, human bladder cancer cells were more sensitive than PBMCs to the cytotoxic effect of MIC. Furthermore, the morphological changes in MIC-treated cells at $24 \mathrm{~h}$ were examined using a 
<smiles>Clc1ccc(COC(Cn2ccnc2)c2ccc(Cl)cc2Cl)c(Cl)c1</smiles>

C
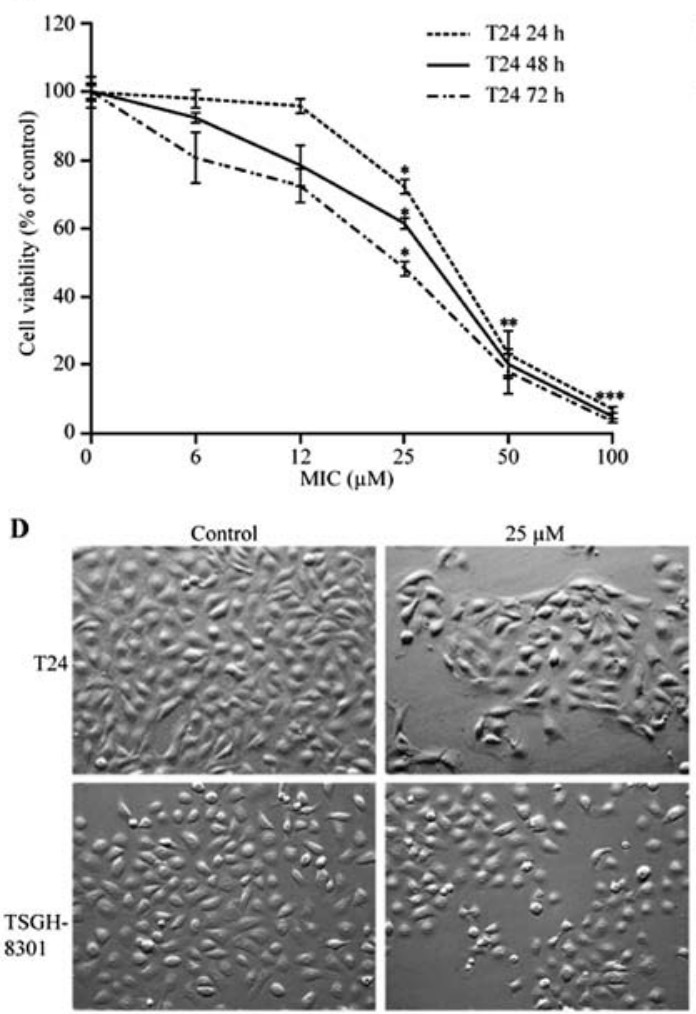

B
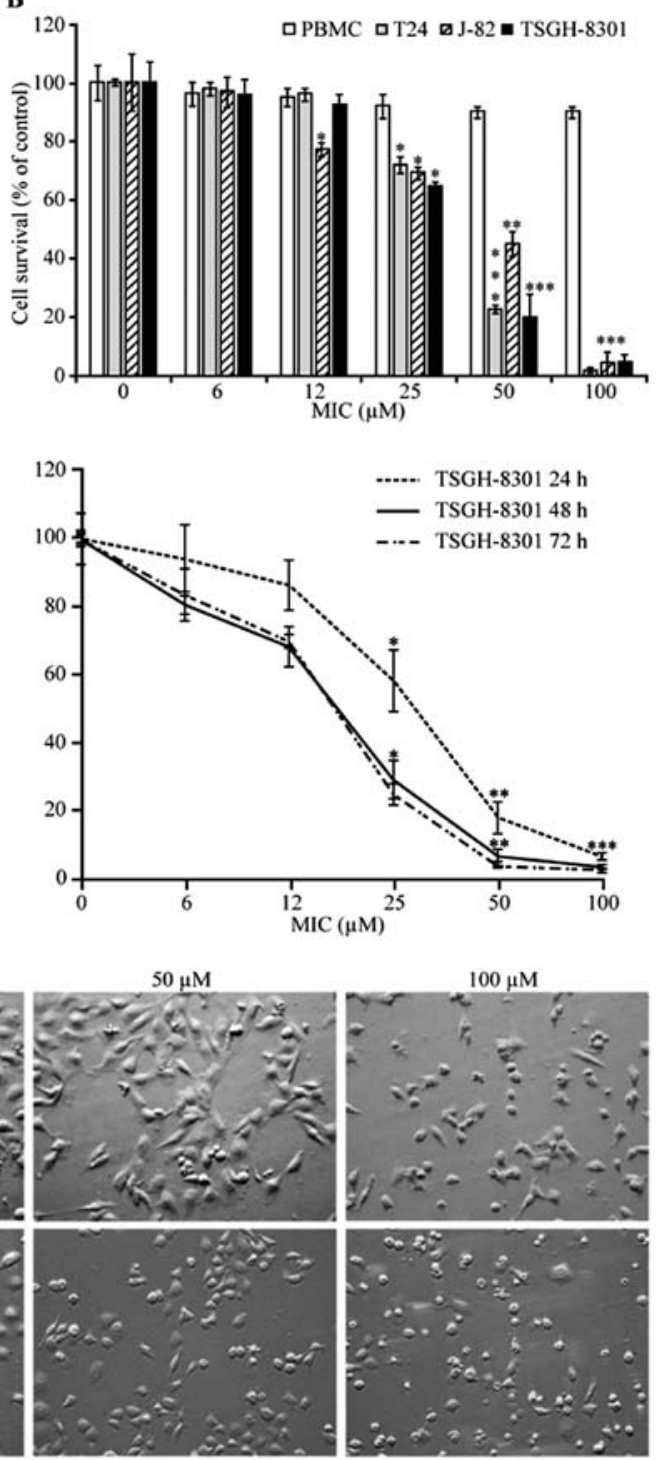

Figure 1. Cytotoxic effects of miconazole (MIC) on human T24, J82 and TSGH-8301 bladder cancer and normal human peripheral blood mononuclear cells (PBMCs). (A) The chemical structure of MIC. (B) T24, J82 and TSGH-8301 cells, and PBMCs were seeded at a density of $2 \times 10^{4}$ cells/well, and then treated with MIC $(6.25,12.5,25,50$ or $100 \mu \mathrm{M})$ or a vehicle control for $24 \mathrm{~h}$. The MTT assay (described in the 'Materials and methods' section) was used to quantify cell viability. (C) T24 and TSGH-8301 cells were also treated with the same concentrations of MIC for 24,48 or $72 \mathrm{~h}$, and then cell viability was assessed with the MTT assay. (B and C) Data points and error bars represent the mean \pm SD of three experiments, respectively. Statistical significance: ${ }^{*} \mathrm{p}<0.05$, ${ }^{* *} \mathrm{p}<0.01$, ${ }^{* * *} \mathrm{p}<0.001$ as compared with the control. (D) Effect of MIC on the morphology of T24 and TSGH-8301 cells. T24 and TSGH-8301 cells were treated with 25 , 50 or $100 \mu \mathrm{M}$ MIC for $24 \mathrm{~h}$. Cells were viewed by a phase contrast microscopy and photographed at a magnification of $\mathrm{x} 200$.

phase-contrast microscope. Cell proliferation in the T24 and TSGH-8301 cells was inhibited with $25 \mu \mathrm{M}$ MIC, but the cells were mostly alive (Fig. 1D). At concentrations of $\geq 50 \mu \mathrm{M}$, MIC induced cell death with marked morphologic changes, such as shrinkage, rounding and floating of the cells, indicating that MIC at higher concentrations induced apoptotic cell death.

MIC induces cell cycle arrest and apoptosis in a p53-dependent manner in T24 and TSGH-8301 cells. To elucidate the mechanism underlying MIC-induced cell death, we analyzed the cell cycle phase distribution in the T24 and TSGH-8301 cells treated with various MIC concentrations for $24 \mathrm{~h}$. The percentage of cells in the sub-G1 phase, indicating cell death, in the T24 and TSGH-8301 cells treated with $75 \mu \mathrm{M}$ MIC $(7.8 \pm 0.3$ and $14.8 \pm 3.5 \%$, respectively; Fig. $2 \mathrm{~A}$ and B) was significantly higher than the percentages in the untreated (control) cells $(0.9 \pm 0.1$ and $1.1 \pm 0.8 \%$, respectively). Additionally, the percentages of T24 cells in G0/G1 transition after treatment with 25 and $50 \mu \mathrm{M} \mathrm{MIC} \mathrm{(65.6 \pm 4.3} \mathrm{and} 76.0 \pm 4.0 \%$, respectively) were significantly higher than that in the untreated cells $(56.8 \pm 4.6 \%$; Table I). Similarly, the percentage $(63.6 \pm 0.4 \%)$ of TSGH-8301 cells in G0/G1 transition after treatment with $25 \mu \mathrm{M}$ MIC was significantly higher than that noted in the untreated cells $(52.7 \pm 1.0 \%$; Table I). Thus, MIC caused G0/G1 cell cycle arrest in both cell lines.

To further investigate the type of cell death caused by MIC, we assessed DNA fragmentation in both types of cells. MIC-treated cells exhibited significant internucleosomal DNA degradation, and elicited a DNA fragment ladder on $2 \%$ gels, which was significantly increased in the T24 and 
A
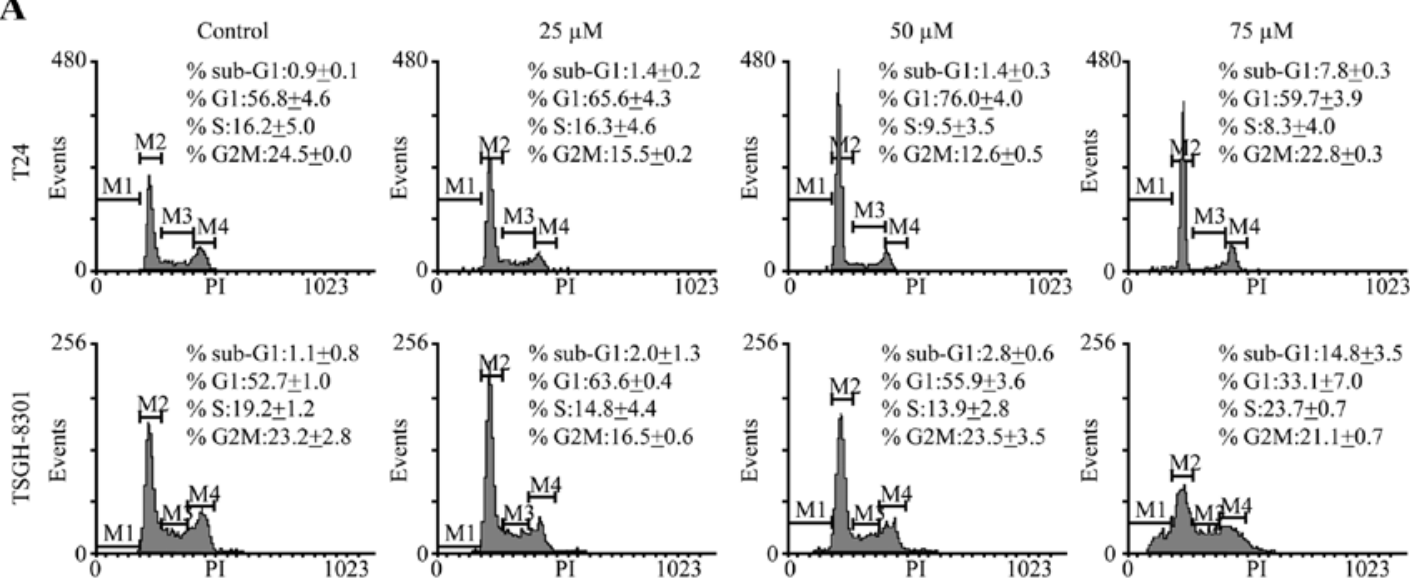

$\mathbf{B}$

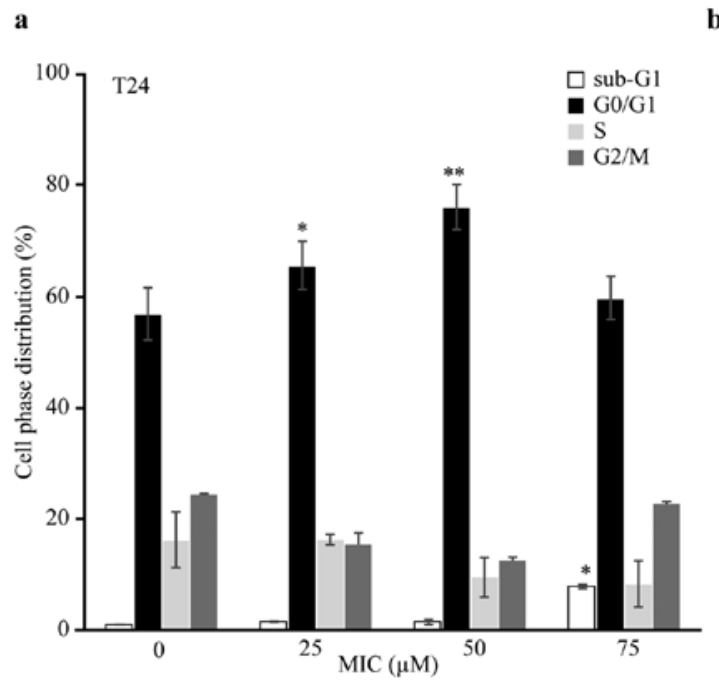

b

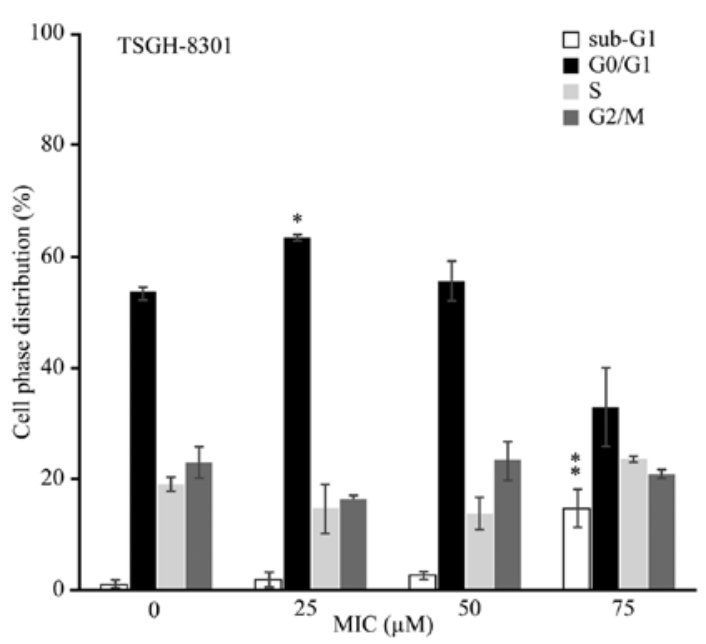

Figure 2. Cell cycle analysis of miconazole (MIC)-treated bladder cancer cells. (A) T24 and TSGH-8301 cells were treated with 25,50 or $100 \mu \mathrm{M}$ MIC for $24 \mathrm{~h}$. Subsequently, the cells were stained with propidium iodide (PI), and then analyzed by flow cytometry. (B) The percentages of (a) T24 and (b) TSGH-8301 cells at each phase of the cell cycle were subjected to statistical analysis. Statistical significance: ${ }^{*} \mathrm{p}<0.05$, and ${ }^{* *} \mathrm{p}<0.01$ as compared with the control.

Table I. Cell cycle phase distribution of T24 and TSGH-8301 cells following MIC treatment.

\begin{tabular}{|c|c|c|c|c|c|}
\hline \multirow[b]{2}{*}{ Cell lines } & \multirow[b]{2}{*}{$\operatorname{MIC}(\mu \mathrm{M})$} & \multicolumn{4}{|c|}{ Cell cycle phase distribution } \\
\hline & & Sub-G1 (\%) & $\mathrm{G} 1(\%)$ & $\mathrm{S}(\%)$ & $\mathrm{G} 2 / \mathrm{M}(\%)$ \\
\hline \multirow[t]{4}{*}{$\mathrm{T} 24$} & 0 & $0.9 \pm 0.1$ & $56.8 \pm 4.6$ & $16.2 \pm 5.0$ & $24.5 \pm 0.0$ \\
\hline & 25 & $1.4 \pm 0.2$ & $65.6 \pm 4.3^{\mathrm{a}}$ & $16.3 \pm 4.6$ & $15.5 \pm 0.2$ \\
\hline & 50 & $1.4 \pm 0.3$ & $76.0 \pm 4.0^{\mathrm{a}, \mathrm{b}}$ & $9.5 \pm 3.5$ & $12.6 \pm 0.5$ \\
\hline & 100 & $7.8 \pm 0.3^{\mathrm{a}}$ & $59.7 \pm 3.9$ & $8.3 \pm 4.0$ & $22.8 \pm 0.3$ \\
\hline \multirow[t]{4}{*}{ TSGH-8301 } & 0 & $1.1 \pm 0.8$ & $52.7 \pm 1.0$ & $19.2 \pm 1.2$ & $23.2 \pm 2.8$ \\
\hline & 25 & $2.0 \pm 1.3$ & $63.6 \pm 0.4^{\mathrm{a}}$ & $14.8 \pm 4.4$ & $16.5 \pm 0.6$ \\
\hline & 50 & $2.8 \pm 0.6$ & $55.9 \pm 3.6$ & $13.9 \pm 2.8$ & $23.5 \pm 3.5$ \\
\hline & 100 & $14.8 \pm 3.5^{\mathrm{a}, \mathrm{b}}$ & $33.1 \pm 7.0$ & $23.7 \pm 0.7$ & $21.1 \pm 0.7$ \\
\hline
\end{tabular}

T24 and TSGH-8301 cells were treated without or with MIC $(25,50$ and $100 \mu \mathrm{M})$ for $24 \mathrm{~h}$, and cell cycle distribution was determined using flow cytometry. Data are expressed as mean \pm SD of experiments $(n=3) ;{ }^{\mathrm{p}} \mathrm{p}<0.05$ vs. control; ${ }^{\mathrm{b}} \mathrm{p}<0.01$ vs. control. MIC, miconazole.

TSGH-8301 cells treated with $75 \mu \mathrm{M}$ MIC for $24 \mathrm{~h}$ (Fig. 3A) and $50 \mu \mathrm{M}$ MIC for 24,48 and $72 \mathrm{~h}$ (Fig. 3B) relative to the control. Importantly, TSGH-8301 cells exhibited more DNA fragmentation than T24 cells after $50 \mu \mathrm{M}$ MIC 

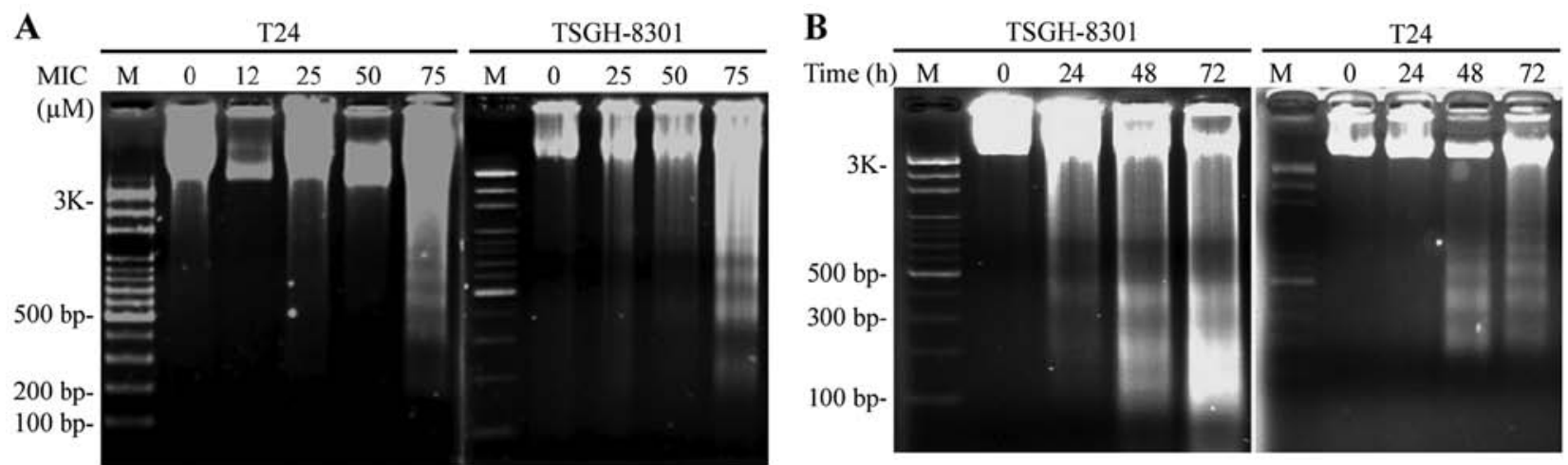

Figure 3. DNA fragmentation analysis of miconazole (MIC)-induced apoptosis in T24 and TSGH-8301 cells. (A) T24 and TSGH-8301 cells were treated with 0,12 or 25,50 and $75 \mu \mathrm{M}$ MIC for $24 \mathrm{~h}$. (B) T24 and TSGH-8301 cells were treated with $50 \mu \mathrm{M}$ MIC for 24, 48 and $72 \mathrm{~h}$, and DNA fragmentation was visualized on $2 \%$ agarose gels.

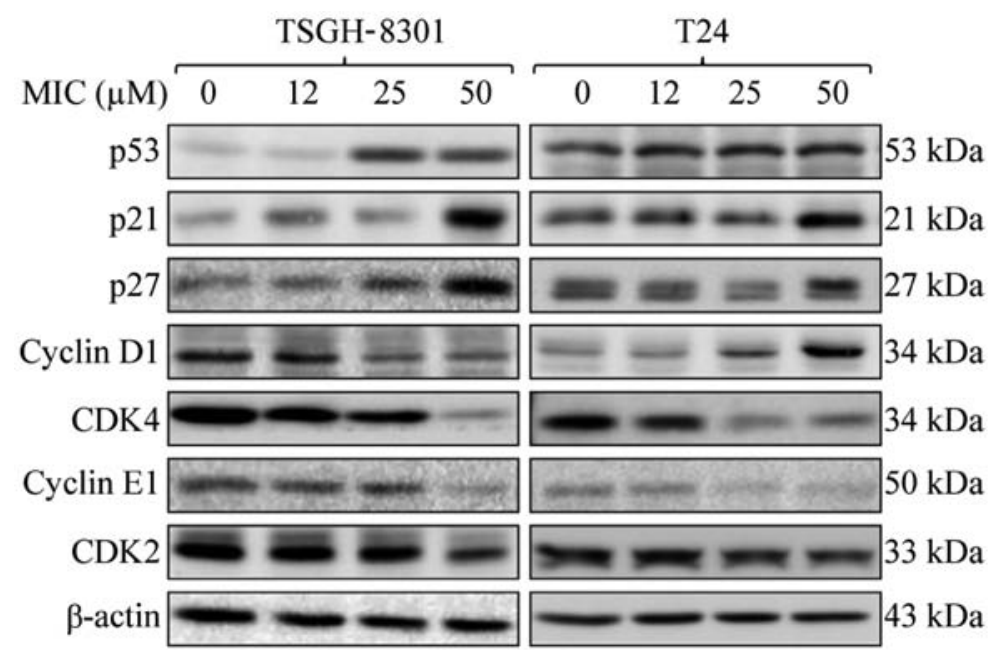

Figure 4. Effect of miconazole (MIC) on the expression levels of G0/G1 phase regulatory proteins in human bladder cancer cell lines with various p53 status. The T24 and TSGH-8301 cells were treated with $12.5,25$ or $50 \mu \mathrm{M}$ MIC for $24 \mathrm{~h}$. The cell lysates $(50 \mu \mathrm{g} / \mathrm{lane})$ were separated by sodium dodecyl sulfate polyacrylamide gel electrophoresis. After electrophoresis, proteins were transferred onto membranes, probed with specific antibodies, and then detected by enhanced chemiluminescence.

treatment for $24 \mathrm{~h}$ (Fig. 3B). This indicated that the TSGH8301 cells, expressing wild-type p53, were more sensitive to MIC-induced apoptosis than the T24 cells, which express p53 with an in-frame deletion of tyrosine 126.

MIC increases $p 21$ and p27 levels, and inhibits cyclin E1, CDK2 and CDK4 expression in T24 and TSGH-8301 cells. We then investigated the roles of cell cycle arrest and p53 in MIC-induced growth inhibition of bladder cancer cells, using western blot analysis. The levels of p21 and p27 were significantly increased, but those of cyclin E1, CDK2 and CDK4 were decreased after treatment with 25 or $50 \mu \mathrm{M}$ MIC in the TSGH-8301 and T24 cells, as compared to these levels in the untreated cells (Fig. 4). Notably, MIC, at 25 and $50 \mu \mathrm{M}$, stimulated p53 expression in the TSGH-8301 (wild-type) cells, but not in the T24 (p53 mutant) cells as compared to the untreated cells. However, 25 or $50 \mu \mathrm{M}$ MIC inhibited expression of cyclin D1, which is required for G1/S transition (20), in the TSGH-8301 cells, resulting in growth arrest. However, MIC at these concentrations stimulated cyclin D1 expression in the T24 cells. Thus, the TSGH-8301 cells were more sensitive to MIC-induced G0/G1 cell cycle arrest than the T24 cells, suggesting that cyclin D1 and possibly p53 are involved in cell cycle arrest. We hypothesized that, in p53-mutant T-24 cells, MIC-stimulated expression of cyclin D1 decreased the susceptibility of these cells to MIC-induced G0/G1 cell cycle arrest as compared with the TSGH-8301 cells.

MIC induces caspase-dependent apoptosis in T24 and TSGH-8301 cells. Apoptotic pathways include the mitochondrial 'intrinsic pathway' and a DR-related 'extrinsic pathway', which involves activation of caspase- $9,-8$, and $-3 /-7$, and cleavage of PARP (21). Thus, to clarify which apoptotic pathway is induced by MIC, levels of the cleaved/activated forms of caspase-8, -9 and -3 , and PARP were determined by western blotting. Cleavage of PARP was induced in the TSGH-8301 and T24 cells treated with 50 and $75 \mu \mathrm{M}$ MIC for $24 \mathrm{~h}$ (Fig. 5A). Therefore, both the mitochondrial and DR pathways were found to be involved in MIC-induced apoptosis in these bladder cancer cells. Moreover, MIC induced a higher level of apoptosis in the TSGH-8301 cells when compared to the T24 cells. Importantly, the level of the cleaved form of 


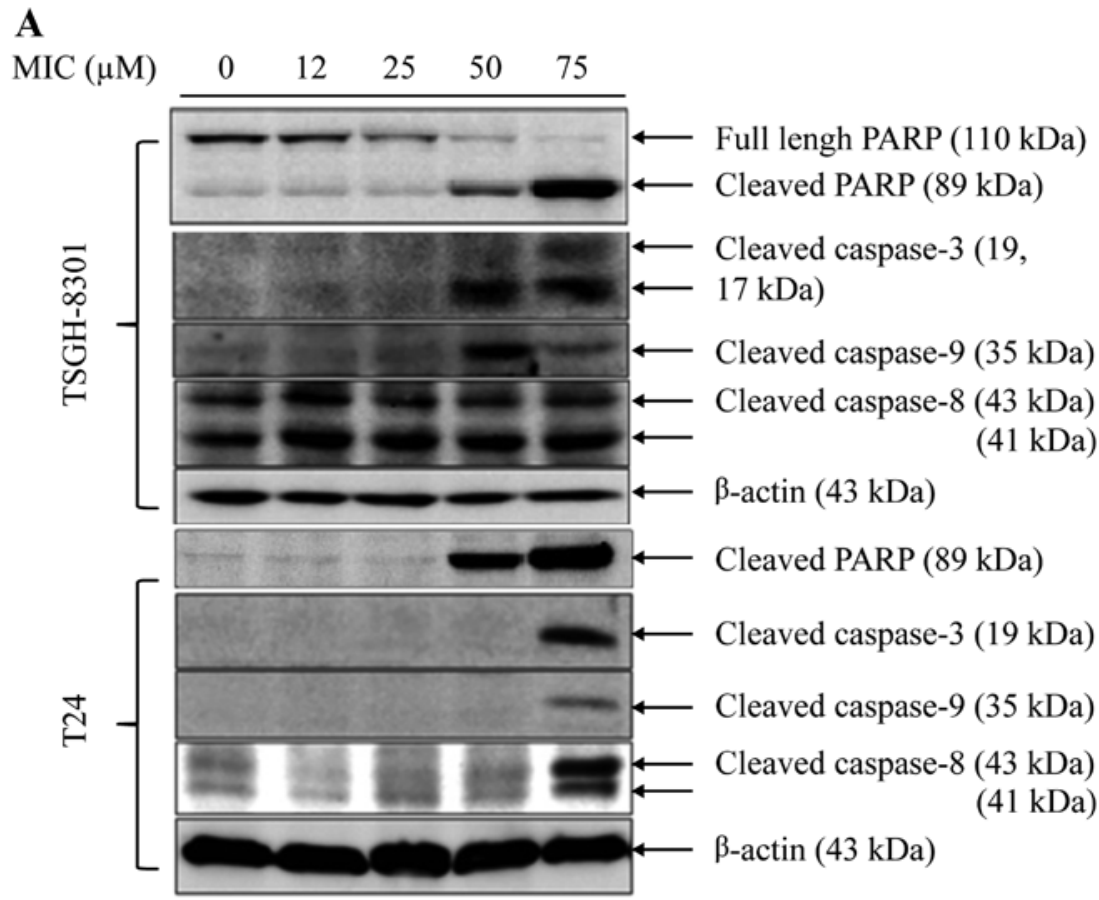

B

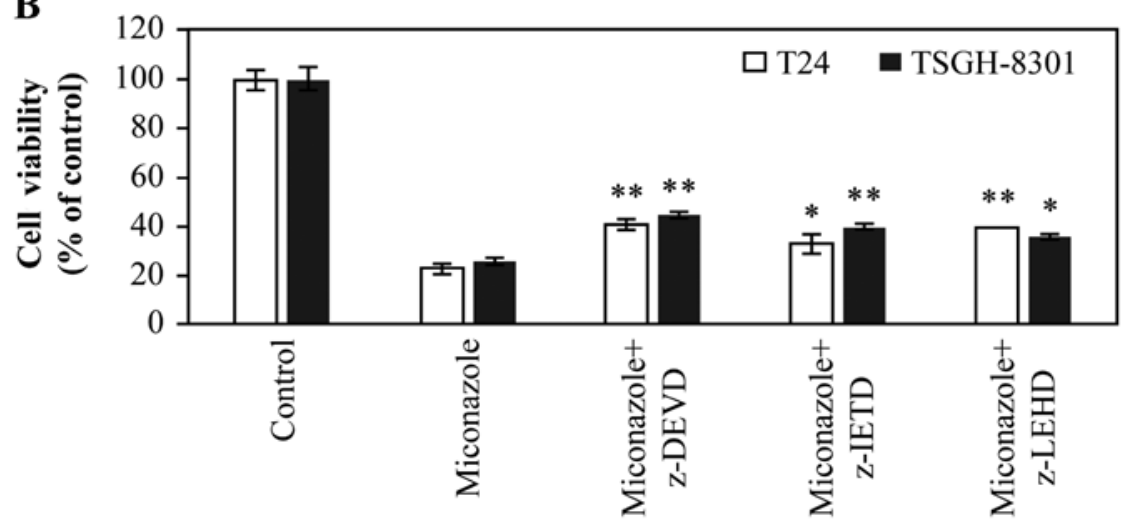

Figure 5. Effect of miconazole (MIC) on caspase activation in the (A) absence and (B) presence of caspase inhibitors in T24 and TSGH-8301 cells. (A) T24 and TSGH-8301 cells were treated with $12,25,50$ or $75 \mu \mathrm{M}$ MIC for $24 \mathrm{~h}$. Total cell lysates were resolved on denaturing polyacrylamide gels and immunoblotted with antibodies against the cleaved forms of caspase- $8,-9$ and -3 , and poly(ADP-ribose) polymerase (PARP). Data are representative of three independent experiments. (B) T24 and TSGH-8301 cells were treated with vehicle only (control) and $50 \mu \mathrm{M}$ MIC in the absence and presence of $10 \mu \mathrm{M}$ z-DEVD (caspase-3 inhibitor), z-IETD (caspase-8 inhibitor) or z-LEHD (caspase-9 inhibitor) for $24 \mathrm{~h}$. The cell viability was then analyzed using MTS assay. Data are expressed as the mean $\pm \mathrm{SD}$ of three independent experiments; ${ }^{*} \mathrm{p}<0.05,{ }^{* *} \mathrm{p}<0.01$; treatment with MIC plus caspase inhibitor vs. MIC alone.

caspase-8 $(\sim 41 \mathrm{kDa})$ was significantly higher in the TSGH-8301 cells than that in the T24 cells after treatment with $\geq 12 \mu \mathrm{M}$ MIC. To determine the roles of capases in MIC-induced apoptosis, the cells were treated with $50 \mu \mathrm{M}$ MIC in the presence of vehicle only (control), or $10 \mu \mathrm{M}$ caspase- $3,-8$ or -9 inhibitors (z-DEVD, z-IETD and z-LEHD, respectively) for $24 \mathrm{~h}$. As shown in Fig. 5B, these caspase inhibitors partially reversed MIC-induced apoptosis in both the T24 and TSGH-8301 cell lines $\left({ }^{*} \mathrm{p}<0.05 ;{ }^{* *} \mathrm{p}<0.01\right)$. Notably, in the T24 cells, there was still a moderate difference between cells treated with MIC plus caspase- 8 inhibitor and those treated with MIC alone $\left({ }^{*} \mathrm{p}<0.05\right)$.

MIC induces DR-mediated apoptosis independent of p53 in T24 and TSGH-8301 cells. To confirm that MIC induces extrinsic apoptosis, we determined the effect of MIC on the expression of proteins in the DR pathway in the T24 and
TSGH-8301 cells. Treatment with $50 \mu \mathrm{M}$ MIC increased expression of DR5 (Fig. 6A), but moderately decreased DR4 levels in both cell lines. However, treatment of these cells with $75 \mu \mathrm{M}$ MIC almost completely abolished the expression of DR4, DR5 and $\beta$-actin (an internal control) (Fig. 6A). This suggests the non-specific cytotoxicity of MIC at $75 \mu \mathrm{M}$. To confirm that DR5 is involved in MIC-induced apoptosis in both cell types, we performed MTT assay. Pre-treatment of cells with anti-DR5 blocking antibody significantly attenuated MIC-induced apoptosis in both types of bladder cancer cell lines (Fig. 6B), indicating that the DR5-mediated apoptosis pathway is involved in MIC-induced apoptosis in bladder cancer cells. To define the role of p53 in MIC-induced cell death, T24 and TSGH-8301 cells were treated with $50 \mu \mathrm{M}$ MIC without or with 1 and $10 \mu \mathrm{M}$ PFT- $\alpha$ (a p53 inhibitor) for $24 \mathrm{~h}$. The cell survival was then determined using MTS assay. As shown in Fig. 6C, PFT- $\alpha$ at $1 \mu \mathrm{M}$, significantly reversed 
A

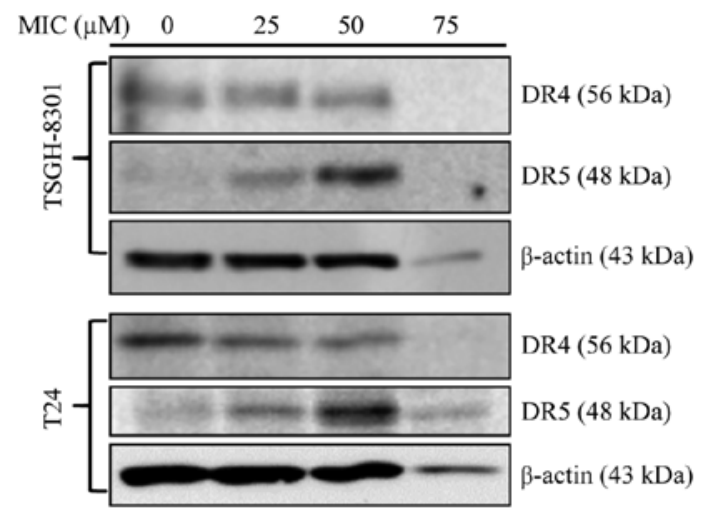

B

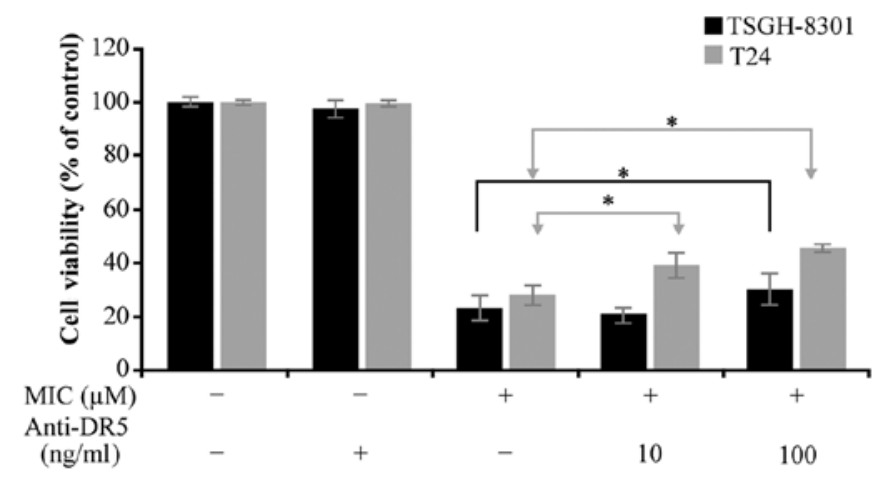

D

C

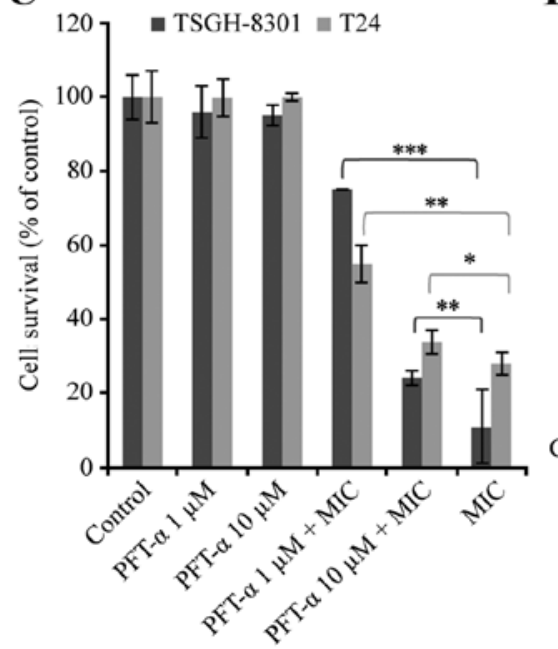

\begin{tabular}{cccc}
\multicolumn{4}{c}{ TSGH-8301 } \\
\hline- & + & - & + \\
- & - & + & +
\end{tabular}

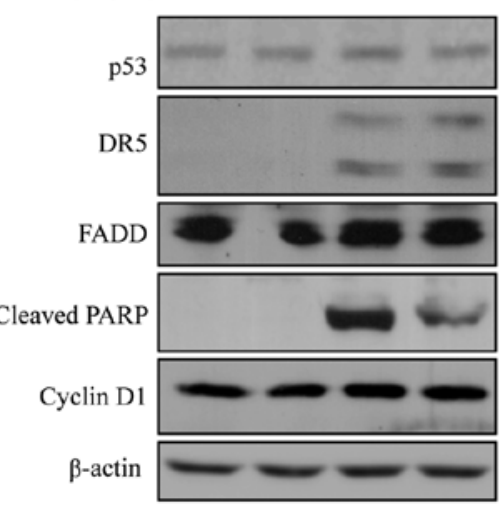

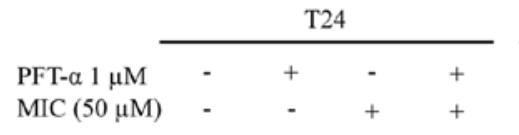

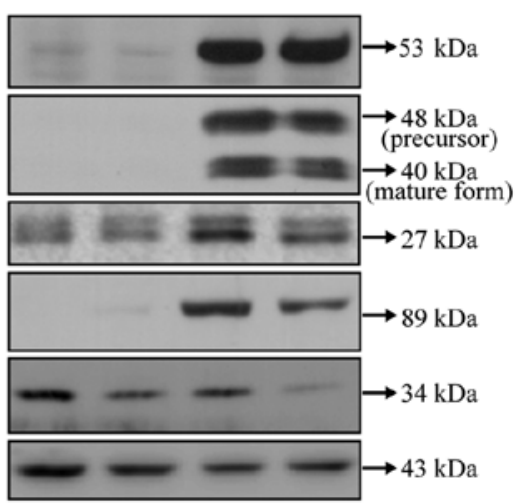

Figure 6. Effects of MIC without or with PFT- $\alpha$ (a putative p53 inhibitor) or anti-DR5 mAb on the expression of proteins involved in (A and D) death receptor (DR)-mediated apoptosis and (B and C) cell viability in T24 and TSGH-8301 cells. (A) T24 and TSGH-8301 cells were treated with $0,25,50$ or $75 \mu \mathrm{M}$ MIC for $24 \mathrm{~h}$. Western blotting of cell lysates was performed with antibodies against DR4, DR5 and $\beta$-actin. (B) T24 and TSGH-8301 cells were incubated with the blocking anti-DR $5 \mathrm{mAb}$, at 10 or $100 \mathrm{ng} / \mathrm{ml}$ for $2 \mathrm{~h}$ at $37^{\circ} \mathrm{C}$ before being co-cultured with MIC at $50 \mu \mathrm{M}$. After incubation of cells with $\mathrm{MIC}(50 \mu \mathrm{M}) \pm 10$ or $100 \mathrm{ng} / \mathrm{ml}$ of anti-DR5 antibody for $24 \mathrm{~h}$ at $37^{\circ} \mathrm{C}$, cell viability was assayed with MTT assay. (B and C) Data are mean \pm SD of three independent experiments; ${ }^{*} \mathrm{p}<0.05,{ }^{* *} \mathrm{p}<0.01,{ }^{* * *} \mathrm{p}<0.001$. (C) T2 4 and TSGH-8301 cells were treated with $50 \mu \mathrm{M}$ MIC \pm 1 and $10 \mu \mathrm{M}$ PFT- $\alpha$ (p53 inhibitor) for $24 \mathrm{~h}$. The cell survival was then determined using MTS assay. (D) T24 and TSGH-8301 cells were treated with vehicle only or $50 \mu \mathrm{M}$ MIC $\pm 1 \mu \mathrm{M}$ PFT- $\alpha$ for 24 h. Western blotting of cell lysates was performed using antibodies against p53, DR5, FADD, cleaved PARP, cyclin D1 and $\beta$-actin.

MIC-induced cytotoxicity in both cell types, particularly TSGH-8301 cells which express wild-type p53. PFT- $\alpha$ treatment attenuated MIC-increased expression of cleaved PARP in the T24 and TSGH-8301 cells and cyclin D1 only in the T24 cells (Fig. 6D). PFT- $\alpha$ treatment attenuated MIC-increased expression of cleaved PARP in the T24 and TSGH-8301 cells and cyclin D1 in the TSGH-8301 cells (Fig. 6D). These results suggest that MIC induced apoptosis in T24 cells in a p53-independent, but cyclin D1-dependent manner.

MIC induces apoptosis through the ROS-mediated mitochondrial pathway in T24 and TSGH-8301 cells. To confirm that the intrinsic, mitochondrial pathway is involved in MIC-induced bladder cancer cell apoptosis, we measured $\Delta \psi \mathrm{m}$ in MIC-treated T24 and TSGH-8301 cells using the fluorescent cationic dye JC-1; loss of $\Delta \psi \mathrm{m}$ is an indicator of mitochondrial damage during apoptosis (22). JC-1 aggregates in normally polarized mitochondria, emitting red fluorescence, but in apoptotic depolarized cells, where $\Delta \psi \mathrm{m}$ is reduced, JC-1 is diffused as monomers throughout the cells and emits green fluorescence. A concentration-dependent decrease in red fluorescence was observed and the ratios of green/red fluorescence were estimated in the $75 \mu \mathrm{M}$ MIC-treated T24 and TSGH-8301 cells (98.1/1.6 and 97.8/1.9\%, respectively; Fig. 7A and B). This indicated that MIC treatment reduced $\Delta \psi \mathrm{m}$ in both cancer cell lines.

We then examined the expression of the proapoptotic protein Bax (23), which triggers cytochrome $c$ release, and of Bcl-2, an anti-apoptotic protein, which inhibits cytochrome $c$ release (24). Treatment of T24 and TSGH-8301 cells with $>50 \mu \mathrm{M}$ MIC for $24 \mathrm{~h}$ resulted in increased expression of Bax and/or cleaved Bax protein, and decreased expression of Bcl-2 protein in the T24 cells (Fig. 7C). Since loss of $\Delta \psi \mathrm{m}$ promotes the release of cytochrome $c$ and Smac/DIABLO into the cytosol (21), we determined the levels of cytochrome $c$ and Smac/DIABLO in the cytosolic fractions of 
A
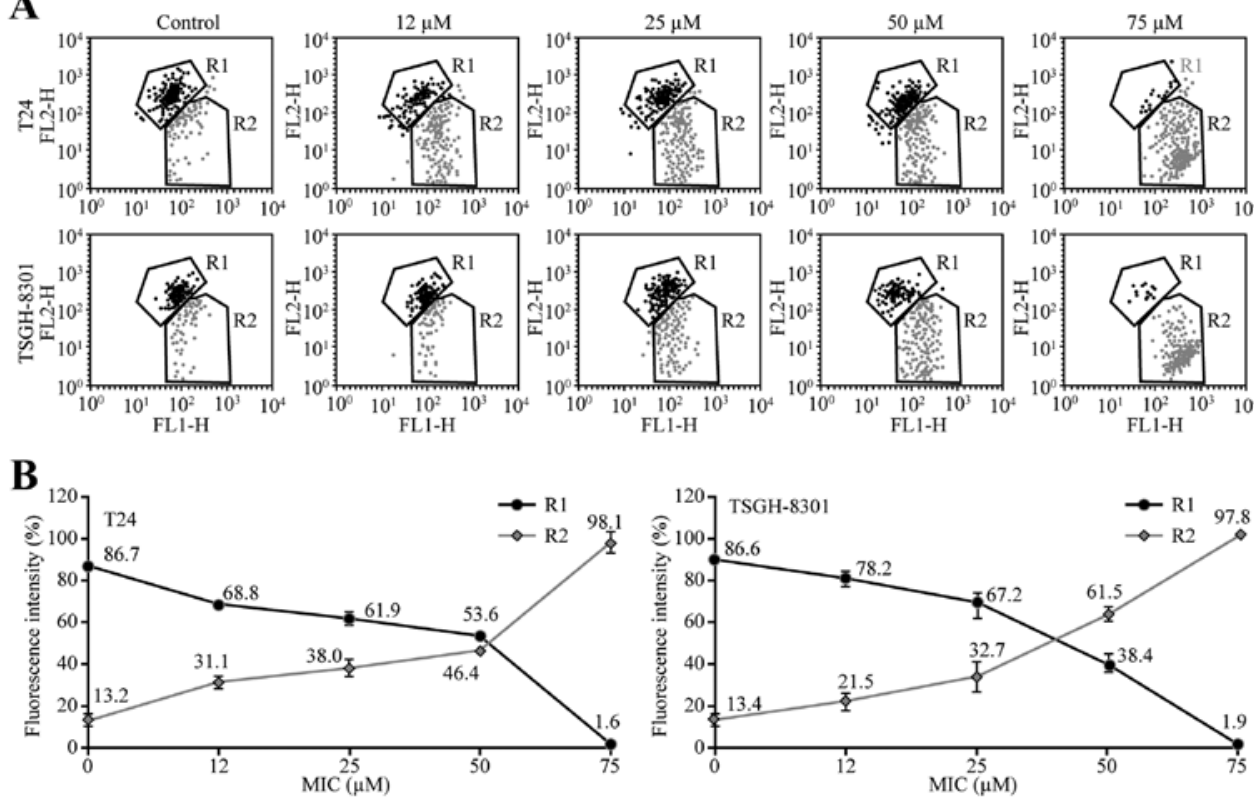

C

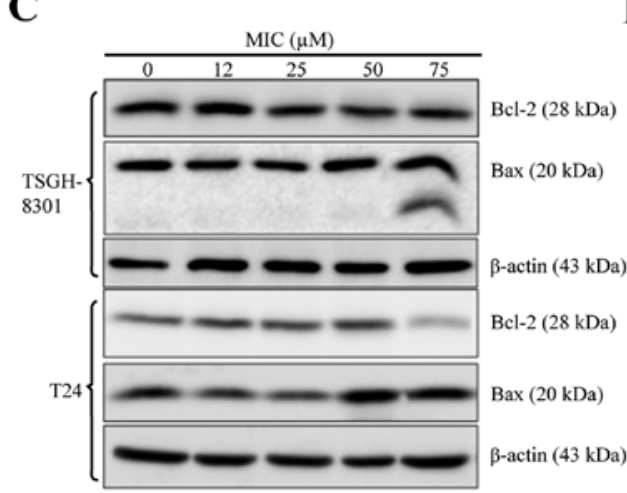

D

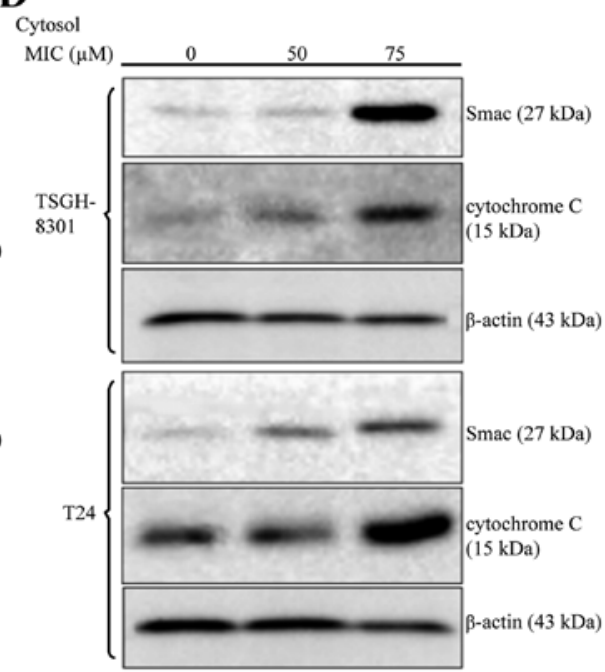

Figure 7. Effect of miconazole (MIC) on mitochondrial-mediated apoptosis in T24 and TSGH-8301 cells. (A) T24 and TSGH-8301 cells were stained with JC-1 dye (R1, aggregated JC-1, red fluorescence; R2, monomeric JC-1, green fluorescence) and then the red:green fluorescence ratio, which indicates changes in the mitochondrial membrane potential, was measured by flow cytometry. (B) The fluorescence intensities of red:green ratio with JC-1 stain in the T24 and TSGH-8301 cells were counted. (C and D) Cell lysates were resolved on denaturing polyacrylamide gels and then western blotting was performed with Bcl-2, Bax, anti-cytochrome $c$ and Smac/DIABLO antibodies, with $\beta$-actin used as an internal control. Data are representative of three independent experiments.

T24 and TSGH-8301 cells that were treated with higher concentrations of MIC (50 and $75 \mu \mathrm{M})$. As shown in Fig. 7D, MIC increased cytochrome $c$ and Smac/DIABLO levels in the cytosol in a concentration-dependent manner in both T24 and TSGH-8301 cells. Taken together, these results indicated that the mitochondrial pathway was also involved in the MIC-induced apoptosis. Since ROS can alter the cellular redox state and $\Delta \psi \mathrm{m}(25,26)$, we investigated whether MIC-treated T24 and TSGH-8301 cells produce ROS. DHE staining yielded increased red fluorescence intensity (Fig. 8A) and ROS production (Fig. 8B) in both MIC-treated cell lines over time (8-24 h). Furthermore, JC-1 staining yielded increasing green fluorescence intensity in both cell lines during the same period (Fig. 8C and D), indicating a reduction in $\Delta \psi \mathrm{m}$. Moreover, pre-treatment of these cells with the antioxidant
$N$-acetyl-L-cysteine (NAC) increased cell survival rates $(\sim 10 \%)$ in both types of cells (Fig. 8E). Collectively, these results suggest that MIC-induced mitochondrial-mediated apoptosis is associated with ROS production in bladder cancer cells.

\section{Discussion}

In the present study, we demonstrated that MIC inhibits cell growth in human bladder cancer cells in vitro by inducing both mitochondrial- and DR5-mediated apoptosis.

The cytotoxic effects of MIC in both bladder cancer cell lines were similar to that previously reported for colon cancer cells (COLO205; $\left.\mathrm{IC}_{50} \sim 50 \mu \mathrm{M}\right)$ (12). MIC caused cell cycle arrest at G0/G1 transition in both the T24 and TSGH-8301 
A
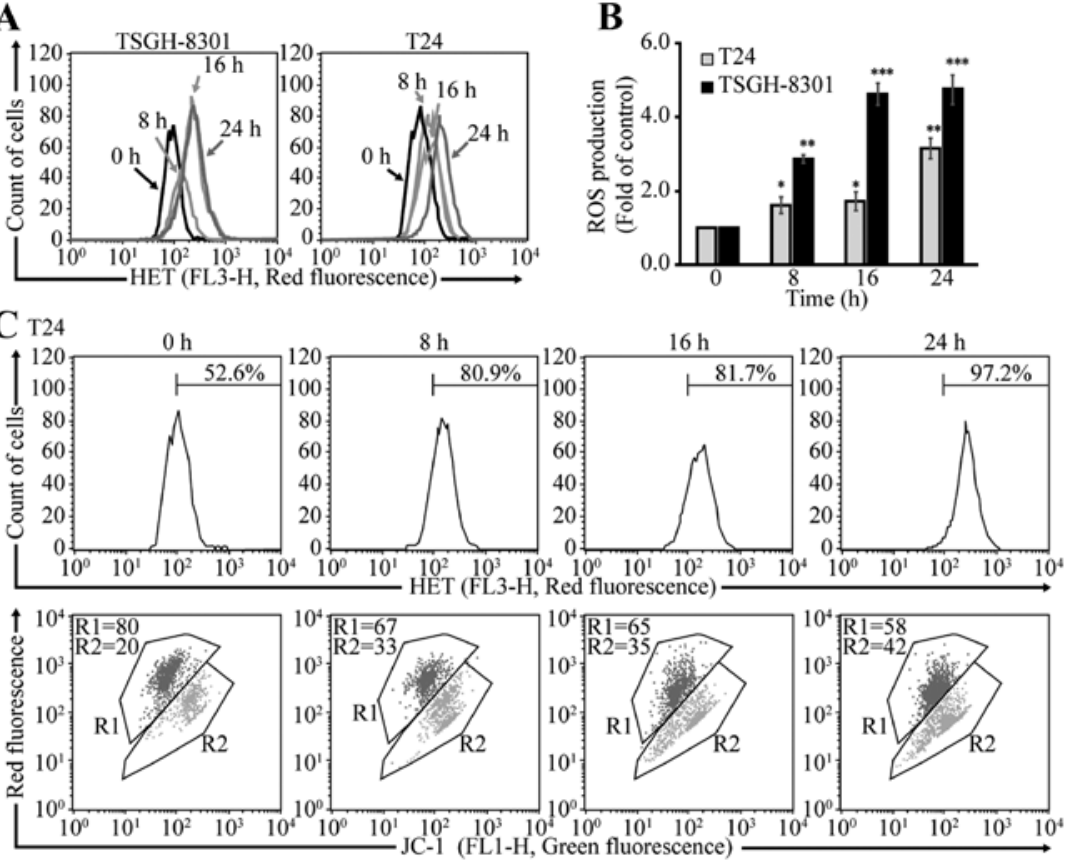

D TSGH-8301
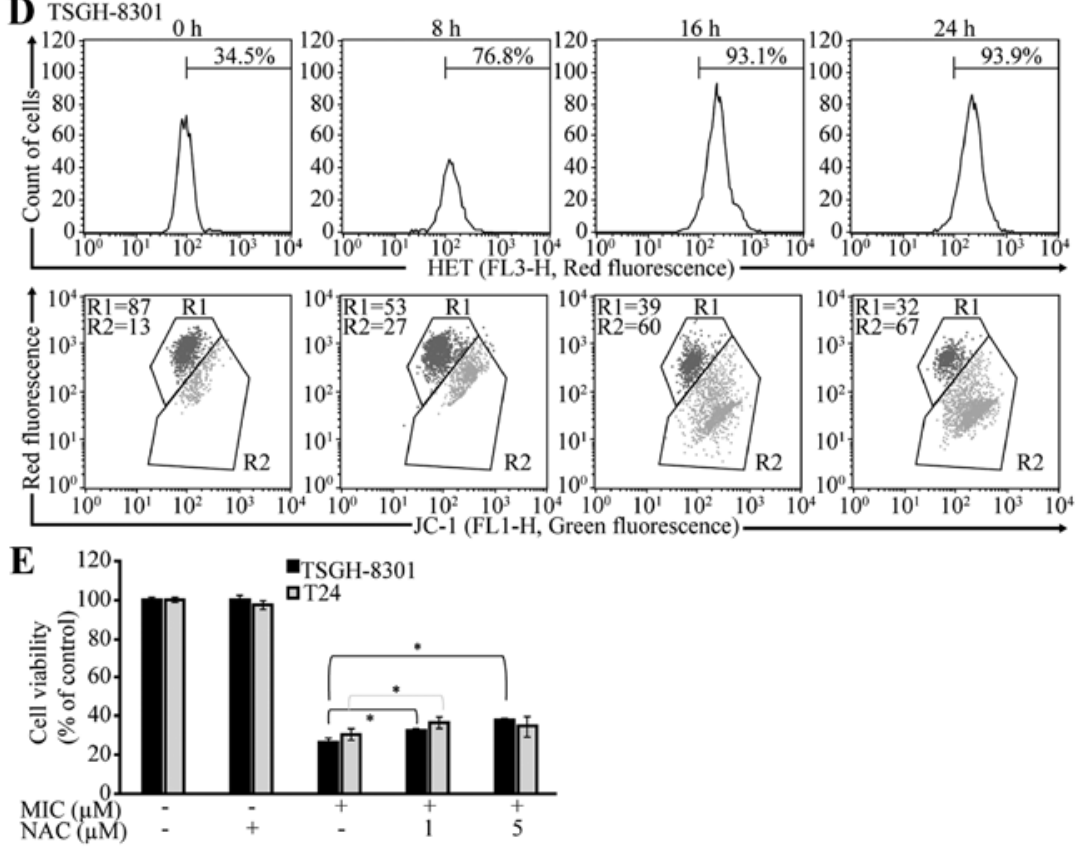

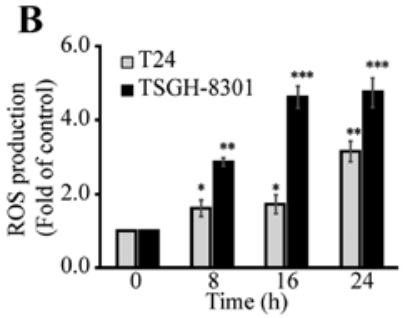

Figure 8. Reactive oxygen species (ROS) production in miconazole (MIC)-induced mitochondrial-mediated apoptosis in T24 and TSGH-8301 cells. T24 and TSGH-8301 cells were treated with $50 \mu \mathrm{M}$ MIC for 8, 16 or $24 \mathrm{~h}$. (A) MIC-treated cells and vehicle only-treated (control) cells were stained with dihydroethidine (DHE), and then the intensity of red fluorescence was measured by flow cytometry. (B) Control cells were set as 1-fold. (B and E) Data are mean \pm SD of three independent experiments $\left({ }^{*} \mathrm{p}<0.05,{ }^{* *} \mathrm{p}<0.01,{ }^{* * *} \mathrm{p}<0.001\right)$. (C and D) Red and green fluorescence intensity in MIC-treated cells relative to control cells was determined by FL3-H and FL1-H intensity, respectively. Green fluorescence is a measure of the mitochondrial membrane potential. (E) Effects of $N$-acetylL-cysteine (NAC) on ROS production in T24 and TSGH-8301 cells. Exponentially growing cells were pretreated with 1 or $5 \mathrm{mM}$ NAC for $1 \mathrm{~h}$. Subsequently, T24 and TSGH-8301 cells were treated with $50 \mu \mathrm{M}$ MIC or DMSO (vehicle control) or NAC (1 or $5 \mathrm{mM}$ ) for 24 h. Cell viability was assayed with MTS assay. Statistical significance indicates three independent experiments; ${ }^{*} \mathrm{p}<0.05$; treatment with MIC plus NAC vs. MIC alone.

cells. The tumor-suppressor p53 plays a pivotal role in cell growth arrest and apoptosis $(27,28)$. Western blotting revealed the elevation of p21 and p27 kinase inhibitors in both MIC-treated bladder cancer cells and a decrease in cyclin E1, CDK2 and CDK4 kinase. Given the differential expression of tumor-suppressor p53 and cyclin D1 kinase in the two bladder cancer cell lines used, we hypothesized that the effect of MIC on cyclin D1 expression in these cells is dependent on the p53 status. MIC induced downregulation of cyclin D1 in the
TSGH-8301 cells (expressing wild-type p53), but not in the T24 cells (expressing p53 mutant). This was evidenced by the additive effect of MIC and PFT- $\alpha$ on the downregulation of cyclin D1 in the TSGH-8301 cells (Fig. 6D). The downstream protein of p53, p21/WAF1 (also known as cyclin-dependent kinase inhibitor), which binds to and inhibits the activity of cyclin-CDK2 and CDK4/6 complexes, functions as a regulator of cell cycle progression at the G1 and S phases (29). The expression of the corresponding gene is tightly controlled by 
p53, through which p21 mediates p53-dependent cell cycle $\mathrm{G}_{1}$ phase arrest in response to a variety of stress stimuli (30).

Additionally, p27 belongs to the Cip/Kip family of CDK inhibitors, which prevents activation of cyclin E-CDK2 or cyclin D-CDK4 complexes, thus controlling cell cycle progression at G1 (31). Therefore, MIC may cause cell death in both bladder cancer cell lines by arresting the G0/G1 phase of the cell cycle. The magnitude of MIC-induced apoptosis in the two bladder cancer cell lines was found to be associated with the p53 status. These results also supported the hypothesis that MIC-induced cell-growth inhibition in both bladder cancer cell lines involves the p53 pathway. Furthermore, higher MIC doses (50 and $75 \mu \mathrm{M}$ ) induced apoptosis in both bladder cancer cell lines, as demonstrated by DNA fragmentation and increased caspase-9, -8 and -3, and PARP levels. Caspases play pivotal roles in the initiation and execution of the DR- and mitochondrial-mediated apoptotic pathways. Our data also revealed that MIC-induced apoptosis in both bladder cancer cell lines was associated with the p53 status, and that TSGH-8301 cells were more susceptible than T24 cells to MIC-induced cell apoptosis. Notably, a putative p53 inhibitor, PFT- $\alpha$, at 1 and $10 \mu \mathrm{M}$, effectively protected both TSGH-8301 and T24 cell types from MIC $(50 \mu \mathrm{M})$-induced apoptosis or cell death as compared to cells treated with MIC alone, regardless of the presence or absence of p53 mutation in these cells (Fig. 6C). We reason that PFT- $\alpha$ protects against MIC-induced apoptosis or cell death in a p53-independent, but in a cyclin D1-dependent manner in T24 cells. MIC $(50 \mu \mathrm{M})$ increased the expression of cyclin D1 in the T24 cells, but attenuated cyclin D1 expression in the TSGH-8301 cells as compared with the control cells treated without MIC. PFT- $\alpha$ is known to protect cancer cells (HCT116) from DNA damage-induced apoptosis by a p53-independent mechanism involving cyclin D1 (32). Notably, PFT- $\alpha$ did not affect the expression of p53 and DR5, but protected against apoptosis in both the T24 and TSGH- 8301 cells treated with MIC as evidenced by decreased levels of cleaved PARP in these cells (Fig. 6D). The reason that PFT- $\alpha$ did not significantly affect the expression of p53, or other transcriptional factors, such as NF- $\kappa \mathrm{B}(33,34), \mathrm{C} / \mathrm{EBP}$ homologous protein $(35,36)$, Elk 1 (2) and YY1 (37) is not clear. It may be under the influence of DR5 expressed in these cells treated with MIC. Activation of caspase- 8 is associated with the DR signaling cascade and the extrinsic pathway (38). Our results revealed that both bladder cancer cell lines treated with $\geq 50 \mu \mathrm{M}$ MIC for $24 \mathrm{~h}$ exhibited upregulation of caspase-8 and DR5. However, apoptosis was partially blocked with an anti-DR5 blocking antibody. Thus, we speculate that MIC induces apoptosis through the DR pathway by activation of caspase- 8 and the downstream caspase- 3 in both bladder cancer cell lines.

ROS cause $\Delta \psi \mathrm{m}$ dysfunction and release of cytochrome $c$, which activates caspase-3, leading to mitochondrial-mediated apoptosis (39). MIC has been shown to induce actin cytoskeleton stabilization and ROS accumulation upon killing of yeast cells (7). We demonstrated that MIC induced mitochondrialmediated apoptosis in the T24 and TSGH-8301 bladder cancer cells, as determined by $\Delta \psi \mathrm{m}$ decrease, the release of cytochrome $c$ and Smac/DIABLO, activation of caspase-9 and -3, and a change in the Bax/Bcl-2 ratio (23). Treatment with higher doses of MIC enhanced ROS levels in both bladder cancer cell lines, which paralleled the decrease of $\Delta \psi \mathrm{m}$ over the same period, but this effect was blocked by the antioxidant NAC. Thus, MIC-induced apoptosis in the T24 and TSGH-8301 bladder cancer cells involved the mitochondrial pathway and was modulated by ROS generation.

In conclusion, we demonstrated that MIC caused G0/G1 cell cycle arrest in human bladder cancer cells, and thus, induced apoptosis in these cells through both the extrinsic DR5-dependent and intrinsic mitochondrial-mediated pathways. MIC appeared to cause cell cycle arrest through both p53-independent and ROS-dependent mechanisms, as evidenced by the inability of NAC to influence the protective effect of PFT- $\alpha$ on MIC-induced cell cycle arrest (data not shown). Since MIC has been shown to interact with lipid rafts/caveolae in target cells (7), we hypothesized that MIC causes cell cycle arrest and activates both apoptosis pathways, at least in part, by interaction with lipid rafts/caveolae in the plasma membrane, where DR5 transduces signaling (40). MIC has been widely used as an antifungal agent without severe side effects, even with prolonged use $(5,41,42)$. Thus, the anticancer effect of MIC may be of potential clinical significance for the treatment of bladder cancer in humans.

\section{Acknowledgements}

The present study was supported by the Taichung Veterans General Hospital, and the Hung Kung University (grant no. TCVGH-HK1028007).

\section{References}

1. Garcia-Cuesta C, Sarrion-Pérez MG and Bagán JV: Current treatment of oral candidiasis: A literature review. J Clin Exp Dent 6: e576-e582, 2014.

2. Oh YT, Liu X, Yue P, Kang S, Chen J, Taunton J, Khuri FR and Sun SY: ERK/ribosomal S6 kinase (RSK) signaling positively regulates death receptor 5 expression through co-activation of CHOP and Elk1. J Biol Chem 285: 41310-41319, 2010.

3. Diehl KB: Topical antifungal agents: An update. Am Fam Physician 54: 1687-1692, 1996.

4. Nawrot U, Nowicka J, Juszczak K and Gusin B: Susceptibility to antifungal agents of Candida species isolated from paediatric and adult patients with haematological diseases. Mycoses 48: 385-390, 2005.

5. Piérard GE, Hermanns-Lê T, Delvenne $P$ and PiérardFranchimont C: Miconazole, a pharmacological barrier to skin fungal infections. Expert Opin Pharmacother 13: 1187-1194, 2012.

6. Colin P, Koenig P, Ouzzane A, Berthon N, Villers A, Biserte J and Rouprêt M: Environmental factors involved in carcinogenesis of urothelial cell carcinomas of the upper urinary tract. BJU Int 104: 1436-1440, 2009.

7. François IE, Bink A, Vandercappellen J, Ayscough KR, Toulmay A, Schneiter R, van Gyseghem E, Van den Mooter G, Borgers M, Vandenbosch D, et al: Membrane rafts are involved in intracellular miconazole accumulation in yeast cells. J Biol Chem 284: 32680-32685, 2009.

8. Alvarez J, Montero M and Garcia-Sancho J: High affinity inhibition of $\mathrm{Ca}^{2+}$-dependent $\mathrm{K}^{+}$channels by cytochrome $\mathrm{P}-450$ inhibitors. J Biol Chem 267: 11789-11793, 1992.

9. Kaur R, Dwivedi AR, Kumar B and Kumar V: Recent developments on 1,2,4-triazole nucleus in anticancer compounds: A review. Anticancer Agents Med Chem 16: 465-489, 2016.

10. Bruserud O: Effects of azoles on human acute myelogenous leukemia blasts and $\mathrm{T}$ lymphocytes derived from acute leukemia patients with chemotherapy-induced cytopenia. Int Immunopharmacol 1: 2183-2195, 2001.

11. Shahbazfar AA, Zare P, Ranjbaran M, Tayefi-Nasrabadi H, Fakhri O, Farshi Y, Shadi S and Khoshkerdar A: A survey on anticancer effects of artemisinin, iron, miconazole, and butyric acid on 5637 (bladder cancer) and 4T1 (breast cancer) cell lines. J Cancer Res Ther 10: 1057-1062, 2014. 
12. Wu CH, Jeng JH, Wang YJ, Tseng CJ, Liang YC, Chen $\mathrm{CH}$ Lee HM, Lin JK, Lin CH, Lin SY, et al: Antitumor effects of miconazole on human colon carcinoma xenografts in nude mice through induction of apoptosis and G0/G1 cell cycle arrest Toxicol Appl Pharmacol 180: 22-35, 2002.

13. Mun YJ, Lee SW, Jeong HW, Lee KG, Kim JH and Woo WH: Inhibitory effect of miconazole on melanogenesis. Biol Pharm Bull 27: 806-809, 2004.

14. Chang HT, Chen WC, Chen JS, Lu YC, Hsu SS, Wang JL, Cheng HH, Cheng JS, Jiann BP, Chiang AJ, et al: Effect of miconazole on intracellular $\mathrm{Ca}^{2+}$ levels and proliferation in human osteosarcoma cells. Life Sci 76: 2091-2101, 2005.

15. Yuan SY, Hsu SL, Tsai KJ and Yang CR: Involvement of mitochondrial pathway in Taxol-induced apoptosis of human T24 bladder cancer cells. Urol Res 30: 282-288, 2002.

16. Yuan SY, Cheng CL, Ho HC, Wang SS, Chiu KY, Su CK, Ou YC and Lin CC: Nortriptyline induces mitochondria and death receptor-mediated apoptosis in bladder cancer cells and inhibits bladder tumor growth in vivo. Eur J Pharmacol 761: 309-320, 2015.

17. Xia Z, Lundgren B, Bergstrand A, DePierre JW and Nässberger L: Changes in the generation of reactive oxygen species and in mitochondrial membrane potential during apoptosis induced by the antidepressants imipramine, clomipramine, and citalopram and the effects on these changes by Bcl-2 and Bcl- $\mathrm{X}_{\mathrm{L}}$. Biochem Pharmacol 57: 1199-1208, 1999.

18. Bindokas VP, Jordán J, Lee CC and Miller RJ: Superoxide production in rat hippocampal neurons: Selective imaging with hydroethidine. J Neurosci 16: 1324-1336, 1996.

19. Satoh T, Numakawa T, Abiru Y, Yamagata T, Ishikawa Y, Enokido $\mathrm{Y}$ and Hatanaka $\mathrm{H}$ : Production of reactive oxygen species and release of L-glutamate during superoxide anion-induced cell death of cerebellar granule neurons. J Neurochem 70: 316-324, 1998.

20. Zuryń A, Litwiniec A, Gagat M, Drzewucka J, Gackowska L and Grzanka A: The influence of arsenic trioxide on the cell cycle, apoptosis and expression of cyclin D1 in the Jurkat cell line. Acta Histochem 116: 1350-1358, 2014.

21. Wyllie AH, Kerr JF and Currie AR: Cell death: The significance of apoptosis. Int Rev Cytol 68: 251-306, 1980.

22. Wu CS, Chen YJ, Chen JJ, Shieh JJ, Huang CH, Lin PS, Chang GC, Chang JT and Lin CC: Terpinen-4-ol induces apoptosis in human nonsmall cell lung cancer in vitro and in vivo. Evid Based Complement Alternat Med 2012: 818261, 2012.

23. Brunelle JK and Letai A: Control of mitochondrial apoptosis by the Bcl-2 family. J Cell Sci 122: 437-441, 2009.

24. Shimizu S, Narita M and Tsujimoto Y: Bcl-2 family proteins regulate the release of apoptogenic cytochrome $c$ by the mitochondrial channel VDAC. Nature 399: 483-487, 1999.

25. Simon HU, Haj-Yehia A and Levi-Schaffer F: Role of reactive oxygen species (ROS) in apoptosis induction. Apoptosis 5: 415-418, 2000

26. Cheng SB, Wu LC, Hsieh YC, Wu CH, Chan YJ, Chang LH, Chang CM, Hsu SL, Teng CL and Wu CC: Supercritical carbon dioxide extraction of aromatic turmerone from Curcuma longa Linn. induces apoptosis through reactive oxygen species-triggered intrinsic and extrinsic pathways in human hepatocellular carcinoma HepG2 cells. J Agric Food Chem 60: 9620-9630, 2012.

27. el-Deiry WS, Harper JW, O'Connor PM, Velculescu VE, Canman CE, Jackman J, Pietenpol JA, Burrell M, Hill DE, Wang Y, et al: WAF1/CIP1 is induced in $p 53$-mediated $\mathrm{G}_{1}$ arrest and apoptosis. Cancer Res 54: 1169-1174, 1994.
28. Wang H, Yang Z, Liu C, Huang S, Wang H, Chen Y and Chen G: RBP-J-interacting and tubulin-associated protein induces apoptosis and cell cycle arrest in human hepatocellular carcinoma by activating the p53-Fbxw7 pathway. Biochem Biophys Res Commun 454: 71-77, 2014.

29. Gartel AL and Radhakrishnan SK: Lost in transcription: p21 repression, mechanisms, and consequences. Cancer Res 65: 3980-3985, 2005.

30. Li H, Qian W, Weng X, Wu Z, Li H, Zhuang Q, Feng B and Bian Y: Glucocorticoid receptor and sequential P53 activation by dexamethasone mediates apoptosis and cell cycle arrest of osteoblastic MC3T3-E1 cells. PLoS One 7: e37030, 2012.

31. van de Mark K, Chen JS, Steliou K, Perrine SP and Faller DV: Alpha-lipoic acid induces p2 $7^{\mathrm{Kip}}$-dependent cell cycle arrest in non-transformed cell lines and apoptosis in tumor cell lines. J Cell Physiol 194: 325-340, 2003.

32. Sohn D, Graupner V, Neise D, Essmann F, Schulze-Osthoff K and Jänicke RU: Pifithrin-alpha protects against DNA damageinduced apoptosis downstream of mitochondria independent of p53. Cell Death Differ 16: 869-878, 2009.

33. Ravi R, Bedi GC, Engstrom LW, Zeng Q, Mookerjee B, Gélinas C, Fuchs EJ and Bedi A: Regulation of death receptor expression and TRAIL/Apo2L-induced apoptosis by NF-kappaB. Nat Cell Biol 3: 409-416, 2001.

34. Shetty S, Graham BA, Brown JG, Hu X, Vegh-Yarema N, Harding G, Paul JT and Gibson SB: Transcription factor NF-kappaB differentially regulates death receptor 5 expression involving histone deacetylase 1. Mol Cell Biol 25: 5404-5416, 2005.

35. Yamaguchi $\mathrm{H}$ and Wang HG: CHOP is involved in endoplasmic reticulum stress-induced apoptosis by enhancing DR 5 expression in human carcinoma cells. J Biol Chem 279: 45495-45502, 2004.

36. Yoshida T, Shiraishi T, Nakata S, Horinaka M, Wakada M, Mizutani Y, Miki T and Sakai T: Proteasome inhibitor MG132 induces death receptor 5 through CCAAT/enhancer-binding protein homologous protein. Cancer Res 65: 5662-5667, 2005.

37. Baritaki S, Katsman A, Chatterjee D, Yeung KC, Spandidos DA and Bonavida B: Regulation of tumor cell sensitivity to TRAIL-induced apoptosis by the metastatic suppressor Raf kinase inhibitor protein via Yin Yang 1 inhibition and death receptor 5 up-regulation. J Immunol 179: 5441-5453, 2007.

38. Zhang HT, Wu J, Wen M, Su LJ and Luo H: Galangin induces apoptosis in hepatocellular carcinoma cells through the caspase 8/t-Bid mitochondrial pathway. J Asian Nat Prod Res 14: 626-633, 2012.

39. Yang F, Chen WD, Deng R, Zhang H, Tang J, Wu KW, Li DD, Feng GK, Lan WJ, Li HJ, et al: Hirsutanol A, a novel sesquiterpene compound from fungus Chondrostereum sp., induces apoptosis and inhibits tumor growth through mitochondrial-independent ROS production: Hirsutanol A inhibits tumor growth through ROS production. J Transl Med 11: 32, 2013.

40. Lim SC, Parajuli KR and Han SI: The alkyllysophospholipid edelfosine enhances TRAIL-mediated apoptosis in gastric cancer cells through death receptor 5 and the mitochondrial pathway. Tumour Biol 37: 6205-6216, 2016.

41. Taguchi H, Miyaji M and Yoshida T: Evaluation of miconazole activity contained in human serum to hypha of Aspergillus fumigatus. Nippon Ishinkin Gakkai Zasshi 41: 41-44, 2000 (In Japanese).

42. Eichenfield LF and Bogen ML: Absorption and efficacy of miconazole nitrate $0.25 \%$ ointment in infants with diaper dermatitis. J Drugs Dermatol 6: 522-526, 2007. 